\title{
Consideration on Strengthening the Career Planning Education of College Students in China
}

\author{
Hongmin LIU \\ School of Economics and Management, Zhengzhou University of Light Industry, Zhengzhou,. China \\ lhmmail2002@sina.com
}

\begin{abstract}
In the present situation of growing employment pressure for Chinese college students, to strengthen the career planning education has a great significance on enhancing the employment competition ability of college students. Based on analyzing the practical significance of career planning, this paper analyzed the main problems in the career planning education of college students at present stage from the perspective of students themselves and universities, and then put forward some measures and proposals of improving the career planning education system of college students and promoting the reform of personnel training system, so as to support the implementation of college students' career planning from the system and improve the scientific nature and effectiveness of graduate employment.
\end{abstract}

Keywords-higher education; college students; career planning; personnel training

\section{Introduction}

The employment pressure of college students has become the focus problem concerned by the whole society, and the employment situation of college students will be more severe and less optimistic in a long period of time. The news from the national employment work forum in 2011 pointed out that the scale of graduates in 2010 is six times what it was the beginning of this century, the number of graduates in 2011 reaches 6.6 million, and will reach nearly 7 million in the "12th Five-Year Plan"[1]. Although there are the attention of government and a series of security measures, the employment difficulties of university students are still an objective reality. Efforts from all parties could partially ease the employment pressure, but it is hard to resolve the problem in a short term. So, facing the severe employment situation, to enhance the guidance of students' career planning, penetrate the career planning education throughout the entire university education process, make students face the market flexibly, and enhance their employment competitiveness are particularly necessary and urgent. In fact, with the advancement and achievement of higher education, higher education has become an essential part for students to seek for survival to a certain extent, and evolved an effective way of making career planning and obtaining career success for contemporary college students. Therefore, to establish a new university personnel training system based on reasonable knowledge and ability structure, take market demand as the orientation, career planning as the center and comprehensive quality development as the breakthrough are necessary.

\section{The Practical Significance of Career Planning}

The so-called personal career planning refers to determining appropriate career direction and goals, formulating corresponding plans on the basis of self-understanding, and then providing the most efficient path to career success for individuals. In another word, that is how to organically combine "what I want to do "with "what I can do", and how to achieve the goals under social demands[2]. The career planning is the navigator for students' career success from the perspective of students' self-development, and its practical significance mainly reflects in the following four aspects:

\section{A The Career Planning can Help Students Make the Correct Positioning and Avoid Blind Employment}

The five elements of career planning include knowing yourself, knowing the enemy, choice, objective and action. Among them, knowing you as well as knowing the enemy is the basis of choice, objective and action. The career planning will guide students to analyze, review and determine their objective and subjective factors of personal career, so that they could correctly understand their own personality, have a reasonable, correct and relative accurate positioning in social life, and then make the phenomenon of "blind employment" and "high employment costs" appeared in current job market effectively be controlled, and finally make the human resource allocation more reasonable.

\section{B The Career Planning can Improve the Students ' Ability of Coping with Social Competition}

The modern society, full of "opportunities" and "choice", is a fierce competition era. In order to occupy a favorable position in competition, students must find a platform for their own development. While through the career planning education, students could learn to use scientific methods, purposefully learn and participate relevant training and practice, fully develop their merits, overcome their drawbacks, exploit their potential ability, and improve their career competitiveness so as to achieve their career goals and ideals.

\section{The Career Planning is Beneficial to Promote Students ' Comprehensive Development \\ Career planning education could help students cultivate positive attitude towards life, develop their self-supporting and independent personality, set learning goals, and raise the cultural and professional levels according to social demand}


signals and their own conditions. And it also could help them motivate their entrepreneurial spirit and encourage them to make achievements through their own learning and work.

\section{$D$ The Career Planning is Favorable to Help Students Make Appropriate Adjustments between Life Demands and Work Demands}

In the constantly changing process of domestic labor market and talent demands, career planning could help students adjust their life goals, balance the demands between family and friends, work and personal preferences, and then establish the more appropriate vocational ideal.

\section{The Main Problems in Current Career Planning Education for College Students}

The higher education in China is the elite education which is practiced in a long term, and under the principle of personal interests subordinating to national interests, there are no career options, which resulted in the long-term weakness of career planning education. Currently, the career planning education in Chinese universities has just started, and there are still many problems to be resolved.

\section{A There are Mainly Two Problems from the Perspective of College Students:}

Firstly, the career planning is not clear. Under the severe employment pressure, only a few students have a clear plan on the career planning, but many other students consider that to find a job could only "follow the market". This situation has a certain relationship to the vague employment direction and career planning. According to the survey about college students' career planning jointly implemented by the North Forest Assessment Network, Sina and the magazine of "Chinese college students employment", there are only $12 \%$ of college students who understand their own personality, interests and abilities, $18 \%$ of them realize their career merits and weaknesses, and only $16 \%$ of them clearly know what they like and dislike about the career [3]. College students' contradictory phenomenon about career planning judgment further indicates that they don't really understand the significance of career planning, only know its concept, but ignore the actual implementation.

Secondly, the judging standard of professional value tends to be pragmatic. Currently, college students' judging standards of professional value are shifting from the previous idealism to the apparent pragmatism. And there also exists different degree of pursuing material benefit and utilitarian [4]. On the career selection, college students pay more attention to the economic value of career, while ignoring its ideal value. And during the course of obtaining employment, students blindly pursue their own development, and have apparent utilitarian and high employment expectations, but not start from their own conditions, ability and social demands, which make many university students concentrate in economically developed regions and promising industries, but few talented person engage in bad industries and remote areas, and finally lead to the unequal distribution of human talents and difficulties in finding jobs.

\section{B There are also Mainly Two Troubles from the Perspective} of University:

First, universities lack the deep guidance of career planning. With the worsening employment situation of university students, the students' career planning has been receiving growing attention from universities, but many of them just lip service and lack actual action, which are mainly presented as follows: On the one hand, many universities have not set career course for students, and the knowledge about career planning for students is not comprehensive, so they do not know how to make their career planning. On the other hand, many universities often hold career planning seminars for students only when they will graduate and take career planning education as the "emergency medicine" for employment. In addition, the lecture organizers are often teachers in university career center or related personnel in business, and they lack the practical knowledge and skills of career planning, or lack the understanding for the characteristics of career planning, so the seminars are generally confined to the propaganda of national macro employment policies, or the analysis of career planning from the perspective of business management, which are rarely able to provide concrete and effective career planning guidance for university students.

Second, the career planning education system is also weak. As a systematic project, the related development factors of career planning education are essential. However, most colleges and universities have not set up special education units for career planning, and many universities just implement a mixed institution which are anchored in the career center or anchored in the office of academic affairs. And teachers engaged in career planning guidance are mostly political work cadres of universities or new student instructors from the graduate school. For the lack of professional knowledge and skills, the guidance is less attractive and not ideal. Therefore, chaos of management system leads to poor quality of career education.

IV. The Measures and Proposals of Perfecting Career Education System and Promoting Talent Training Mechanism Reform of University

Currently, the job market of "market-oriented, government's regulation, school's recommendation and divergent selection of students and employers" is gradually taking shape [5]. Paying attention to and enhancing the students' career planning education become an important problem for talent training. For college students, early contacting and understanding the contents of career planning and making their career planning could help them enhance the rationality of job hunting. From colleges and universities, the career planning education should not be just limited to the theoretical study, but also should combine students' actual situation to change their behavior. So, universities should vigorously promote the reform, institutionally improve the career education system and then support students to achieve career planning. 
A The Systematic Career Planning Education Programs and Perfect Career Evaluation System are the Foundation

First, speed up the construction of career planning education programs. To take career planning into class is an effective way to promote students' career planning education. On the one hand, universities should set relevant career planning curriculum according to the objectives and contents of career planning education and form a complete career planning course system, so as to help students understand the relationship between personal development and career planning, promote the establishment of career development vision, guide them to analyze the factors affecting personal career development, master the basic skills of career planning and develop positive professional attitude and professional development view. On the other hand, the career planning education should run through the whole process of university education, and should take the corresponding education methods and means for students with different characteristics. In general, in the freshman phases the university should enable students to deepen their understanding of professional development goals and employment direction, so that they can have a preliminary understanding of future career and lay a good foundation for the establishment of career goals. During the sophomore stage, the university should make students understand the qualities required in the future career, encourage students to train their ability through participating in various practical activities, and revise individual career planning according to personal interests and conditions. After junior, while guiding students to strengthen professional learning and graduation practice, the university should also guide students to focus on improving professional skills and developing their entrepreneurial ability. Meanwhile, the university should purposefully conduct special guidance for students, hire professional consultants and human resources commissioner of business to introduce the industrial demands and organize students to receive career training and participate in job fairs.

Second, establish and improve the career assessment system of career planning. Self-awareness is a complex process, in the process of personal growth and personality formation, although students have certain perceptions and experiences to judge their interests, values, professional aptitude and ability, they often lack scientific basis. Thus, they need the external professional guidance and help, and the scientific and professional career planning guidance is particularly important. Therefore, the university should introduce scientific and professional occupation assessment tools in accordance with characteristics of college students, establish and improve the career assessment system of career planning, so that each student could constantly conduct professional assessment during four years of university education, gradually form a complete understanding of them, and then enhance the reliability and validity of professional assessment. For these reasons, the university should make students conduct career assessment at every stage from entering the school to graduation and establish the management information system of career assessment for each student.

\section{$B$ The System to Support the Implementation of Career} Planning is the Guarantor

Career planning is a systematic project, and systematic career planning education courses and continuing career planning education are only the foundation, and the university should start from the reform of talent training system and support the implementation of career planning. The modern educational philosophy of higher education follows the principle of "student-centered", which must be carried out from the actual situation of students' career development and centered on the improvement of comprehensive quality and the employment ability.

Firstly, further reform the entrance and training system of university and optimize the talent training programs and curriculum settings. On the one hand, it should reform the current professional enrollment patterns, build the system of selecting major after admission and allow students to have full rights to choose their major. In China, after college entrance examination, the students do not carefully consider their own inclinations and interests when fill up college entrance voluntary table, and hastily sign their life as long as finding admitted university. The disadvantage of this approach is not to make a long-term planning based on individual capabilities and features. In the future, the university should vigorously promote the changes from professional recruitment to discipline category enrollment, and allow students to choose their favorite major based on the understanding of discipline construction and social demands. On the other hand, the university should implement the real meaning of credit system and meet the supply and demand contradiction of learning resources between schools and students. From the 1980s, China has began to promote the implementation of credit system, but so far, the credit system in many domestic universities more or less has the color of academic year, and the real meaning establishment of "full credit" is still a process which further needs to deepen and perfect.

Secondly, establish independent system for selecting courses, and constantly revise and update professional development goals of university students. Only construct independent system for selecting courses, can the student career planning be truly ensured. Career planning should meet the social demands. However, Chinese students rarely contact with society and poorly understand the practical demands of society. And the changes of social environment will have a direct impact on career planning, in order to make the previous planning effective, it must constantly evaluate and revise the planning, including the re-selection of career, the choice of career line, the correction and implementation of life goals and changes of plan. The establishment of independent system for selecting courses is more conducive to rationally organize learning resources according to the demands of student career planning and enhance the learning initiative and purpose.

Thirdly, it should promote the establishment of innovation and entrepreneurship mechanisms and the implementation of students career planning. To effectively ensure the implementation of career planning, it should implement the flexible management of learning cycle. On the one hand, students should understand their own career anchor and market demands in order to establish their own career planning. On the 
other hand, when some innovative students have entrepreneurial aspirations and conditions, the university should provide convenience and appropriately relax the year requirements based on the standard academic years. If students could complete all the required credits in advance, they could graduate early. And if students wasted their time owing to venturing or exploring personal professional tendency, the university also should allow a delay graduation and give them strong support for entrepreneurship and advanced study.

\section{Conclusions}

The college stage is a key period for life planning, whether students could do well in their career planning, not only directly relates to the employment competitiveness after they graduate, but also relates to their life direction and goals. And whether students could achieve better employment, not only directly relates to the social harmony and stability, but also relates to the long-term development of students and the most concerned, direct and practical interests of people, and also relates to the country's future. From this perspective, enhancing career planning education and vigorously promoting education reform have great social significance, and should cause great concern of universities and society.

\section{References}

[1] Lei Feng, "How to make the 6.6 million students obtain employment in this year, and more initiatives to crack job problems? " Guangming Daily, February 23, 2011.

[2] Heqing Yang, Career Planning [M]. Beijing: China Labor Social Security Press, 2005.

[3] Xin Xiang, "Research on the status and countermeasure consideration on the college student career planning education," Modern Education Science, 2008(5).

[4] Hongmin LIU, "Research on the Government Responsibility to Employment from the Tendency of Chinese University Students Preference in State-owned Enterprises and as Civil Servants, ” Proceedings of 2011 International Conference on Public Administration, Chengdu, Oct 18-20, 2011.

[5] Rongtao Jiang, "Consideration on college students' career planning and the reform of talent training mode of higher education[J]. Journal of Xiangtan University, 2008 (3). 